\title{
Size-dependent photoacclimation of the phytoplankton community in temperate shelf waters (southern Bay of Biscay)
}

\author{
Eva Álvarez ${ }^{1, *}$, Xosé Anxelu G. Morán ${ }^{1,2}$, Ángel López-Urrutia ${ }^{1}$, Enrique Nogueira ${ }^{1}$ \\ ${ }^{1}$ Instituto Español de Oceanografía, Centro Oceanográfico de Gijón/Xixón, Asturias, Spain \\ ${ }^{2}$ Present address: Red Sea Research Center, King Abdullah University of Science and Technology, Thuwal, Saudi Arabia
}

\begin{abstract}
Shelf waters of the Cantabrian Sea (southern Bay of Biscay) are productive ecosystems with a marked seasonality. We present the results from $1 \mathrm{yr}$ of monthly monitoring of the phytoplankton community together with an intensive sampling carried out in 2 contrasting scenarios during the summer and autumn in a mid-shelf area. Stratification was apparent on the shelf in summer, while the water column was comparatively well mixed in autumn. The size structure of the photoautotrophic community, from pico- to micro-phytoplankton, was tightly coupled with the meteo-climatic and hydrographical conditions. Over the short term, variations in the size structure and chlorophyll content of phytoplankton cells were related to changes in the physico-chemical environment, through changes in the availability of nutrients and light. Uncoupling between the dynamics of carbon biomass and chlorophyll resulted in chlorophyll to carbon ratios dependent on body size. The slope of the size dependence of chlorophyll content increased with increasing irradiance, reflecting different photoacclimation plasticity from pico- to micro-phytoplankton. The results have important implications for the productivity and the fate of biogenic carbon in this region, since the size dependence of photosynthetic rates is directly related to the size scaling of chlorophyll content.
\end{abstract}

KEY WORDS: Phytoplankton · Hydrography · Chlorophyll:carbon ratio · Size spectra · Size scaling · Continental shelf $\cdot$ Cantabrian Sea

\section{INTRODUCTION}

The attributes of the phototrophic plankton community are the result of a variety of biological processes and the influence of the physical environment (Rodriguez 1994). Focusing on eco-physiological attributes of the community may lead to improved understanding of mechanistic linkages between environmental drivers and community composition (McGill et al. 2006, Litchman \& Klausmeier 2008) and may ultimately allow prediction of community structure from first principles of physiology and morphology (Edwards et al. 2013). The most frequently reported attribute of the phytoplankton community is the bio- mass stock, whose variation reflects the balance between gain and loss terms related to physical (i.e. accumulation/dispersion) and biological (i.e. growth/ grazing) processes (Legendre 1990). Because all phototrophic plankton contain chlorophyll a (chl a), phytoplankton biomass is often inferred from this pigment (Huot et al. 2007). Traditionally, chl a has been used as a proxy for phytoplankton biomass since it can be easily measured, in contrast to carbon biomass that is hard to measure directly.

Changes in the proportion of chl a to carbon biomass may indicate an adjustment of cellular pigment levels to match the demands for photosynthesis, which is driven by changes in light, nutrients and 
temperature (Geider 1987). Thus, the concentration of chl a is a biased estimator of phytoplankton biomass expressed in organic carbon units (Cullen 1982), making it necessary to use conversion factors in order to estimate phytoplankton biomass. Using a constant chl a to carbon ( $\mathrm{chl} \mathrm{a:C)} \mathrm{ratio} \mathrm{to} \mathrm{derive}$ phytoplankton biomass from chl a datasets results in considerable bias and uncertainties at regional to global scales (Buck et al. 1996, Wang et al. 2008). The variability of the chl a content resulting from light acclimation and nutrient conditions leads to highly variable chl a:C ratios. It is well known that phytoplankton chl a:C ratios increase with depth owing to a phenomenon called photoacclimation. Hence, it is important to use the appropriate $\mathrm{chl}$ a: C ratios to estimate carbon biomass at regional to global scales (Wang et al. 2013). Although a wide range of values in chl a:C ratios has been reported (Pérez et al. 2006, Gutiérrez-Rodríguez et al. 2010), less is known about the large scale spatial and temporal variations in phytoplankton chl a:C ratios in natural ecosystems.

Recently, more emphasis has been placed on measuring carbon together with chl a on a routine basis, relying not only on a fixed chl a:C ratio. Satellite measurements continuously provide global chl a biomass from ocean colour observations. Advances in satellite ocean colour data analysis now permit separating light-absorbing and scattering components in seawater, yielding simultaneous estimates of chl a and particulate backscattering coefficients $\left(b_{\mathrm{bp}}\right.$, Siegel et al. 2002). Carbon-based models for ocean productivity (Behrenfeld et al. 2005, Westberry et al. 2008) calculate particulate organic carbon from satellite $b_{\mathrm{bp}}$ and infer phytoplankton carbon given the relatively constant proportion of non-algal particles contributing to $b_{\mathrm{bp}}$. The simultaneous estimate of both variables, chl $a$ and phytoplankton carbon, not only circumvents the problem of using chl a as a proxy for biomass, but also allows the estimate of the intra-cellular chl $a$ concentration, which can be used to derive primary production. The growth rate of the phytoplankton community is influenced by nutrient concentration, temperature and light. Nutrient limitation or temperature stress cause a decrease of phytoplankton growth rates that is accompanied by a proportional decrease in chl a: C ratios (Cloern et al. 1995, Behrenfeld et al. 2002). Hence, the effect of nutrients and temperature on growth rate can be approached by the relation of the measured chl a: $\mathrm{C}$ ratio to the maximum potential community chl a:C ratio (Behrenfeld et al. 2005) so that the intracellular concentration of chl a can eventually be used to estimate the growth rate of the phytoplankton community.
The introduction of flow cytometry techniques in oceanography have allowed enumerating and sizing single cells (Yentsch et al. 1983, Sieracki et al. 1998) and estimating cellular biovolume. Accurate estimations of cell biovolume result in better estimations of individual carbon content (Menden-Deuer \& Lessard 2000, Álvarez et al. 2012). Hence, the enumeration of phytoplankton cells by means of flow cytometry provides not only carbon biomass information but also information about the size structure of the community. Allometry is the study of the relationship of body size to different traits of shape, anatomy, physiology or behaviour. The relationship between a measured trait and organism size is often expressed as a power law, where the slope is the scaling exponent of the law.

Pigment content appears as a basic eco-physiological trait that can account for the physiological status of the community and can be explained partly by cell size (Geider et al. 1986, Finkel 2001). A non-linear relationship exists between chl a content and light absorption due to the 'package' effect. This effect can be seen as a reduction in the absorption of pigmented particles within a cell relative to the absorption of the same pigments in solution. The explanation is purely geometrical. Large microalgae have a lower surface to volume ratio, which causes shading effects due to the packaging of pigments; hence, they are more influenced by the package effect than smaller cells, which translates into a size dependence of chl a content as reported in laboratory experiments (Key et al. 2010) and field studies (Pérez et al. 2006, Marañón et al. 2007).

Another consequence of the limitations imposed by the package effect to the larger cells is that they have less plasticity in their pigment content. Hence, the size dependence of the photoacclimation response results in different allometric exponents in the size scaling of chl a content with changing irradiance (Finkel et al. 2004). Although predicted by theory, this variation in the allometric exponents has only been obtained in laboratory studies (Fujiki \& Taguchi 2002), with a lack of field studies to corroborate the variability of the size dependence of chl a content. Our hypothesis is that the coupling of traditional techniques, such as chl a extraction, together with flow cytometry techniques that provide size information, will allow us to evaluate the effect of changes in the package effect with cell size from the size-fractionated sampling of the phytoplankton community. This idea has been introduced in productivity models with multiple size classes, showing a better fit to experimental and field data (Baird et al. 2013). 
In the present work, we analysed the seasonal and short-term dynamics of the meteo-hydrographic scenario and phytoplankton community in the southern Bay of Biscay continental shelf. We present a complete year of monthly sampling in a mid-shelf station coupled to 2 intensive (daily) surveys at the same location carried out in summer and autumn. The goal of the work was to describe the phytoplankton dynamics through the simultaneous measurement of carbon/biovolume and chl $a$, and the coupling with relevant physical variables. This allowed us to (1) state more realistically the variability of the biomass stock and to understand the influence of temperature, irradiance, nutrient concentration and community composition on the in situ dynamics of physiology in situ, analysing the size dependence of photoacclimation processes in the field. The study of 2 different meteo-hydrographic scenarios with high between-regime differences in phytoplankton carbon biomass and pigment content within the context of the seasonal cycle revealed the variability of the underlying size dependence of chl a content for the first time in natural samples.

\section{MATERIALS AND METHODS}

\section{Sampling at sea}

Intensive sampling was carried out at a mid-shelf oceanographic station $\left(43.67^{\circ} \mathrm{N}, 5.58^{\circ} \mathrm{W}\right.$, ca. $110 \mathrm{~m}$ depth at low water) in the central Cantabrian Sea (southern Bay of Biscay) during summer (17-29 August) and autumn (6-23 November) of 2008. The station was visited almost daily around noon (maximum sampling interval 3 d) during these 2 periods. Supplementary oceanographic data acquired monthly at this location within the time-series monitoring programme RADIALES (www.seriestemporales-ieo.com) were used to define the seasonal context (from April 2008 to April 2009). Solar radiation, wind speed and precipitation were recorded on an hourly basis at a meteorological station situated on land near the sampling area (43.54 ${ }^{\circ} \mathrm{N}, 5.62^{\circ} \mathrm{W}, 30 \mathrm{~m}$ above mean sea level).

The water column was sampled with a rosette sampler equipped with Niskin bottles and a conductivitytemperature-depth (CTD) probe (Seabird Electronics 25), with auxiliary sensors for the measurement of fluorescence (SCUFA Turner) and photosynthetically active radiation (PAR, Biospherical/Li-Cor). Vertical profiles of temperature, salinity, in vivo fluorescence and PAR were obtained from the surface (3 $\mathrm{m}$ depth) down to $100 \mathrm{~m}$. The mixed layer depth (MLD) was defined as the depth where the temperature is $0.8^{\circ} \mathrm{C}$ lower than the surface value (Kara et al. 2000). The euphotic zone depth $\left(z_{\text {eu }}, \mathrm{m}\right)$ was estimated as the depth receiving $1 \%$ of the PAR measured at the surface (Kirk 1994). Water samples were collected in Niskin bottles at 8 fixed depths $(3,10,20,30,40,50$, 75 and $100 \mathrm{~m}$ ) for the analysis of nutrients and chl $a$ concentrations. For the analysis of the autotrophic community by means of flow cytometry and FlowCAM, water samples from the bottles were collected by filtering gently through a $200 \mu \mathrm{m}$ mesh at 5 depths in summer $(3,20,40$, deep chl a maximum [DCM] and $75 \mathrm{~m}$ ) and 3 depths in autumn (3,20 and $75 \mathrm{~m})$. The DCM was established on the basis of the vertical profiles of in vivo fluorescence.

\section{Analytical procedures}

Water samples for the analysis of inorganic nutrients (around $5 \mathrm{ml}$ ) were frozen $\left(-20^{\circ} \mathrm{C}\right)$ and kept in the dark until analysis in the laboratory with a Skalar San Plus System auto-analyser. Nutrient concentrations ( $\mu \mathrm{mol} \mathrm{l}^{-1}$ of nitrite, nitrate, silicate and phosphate) were estimated by replicated segmented flow analysis (Grasshoff et al. 1983). The nitracline was defined as the depth where the concentration of nitrate was $1 \mu \mathrm{mol} \mathrm{l}^{-1}$.

Total chl a was estimated from $100 \mathrm{ml}$ of water filtered onto Whatman GF-F filters. For the analysis of size-fractionated chl $a$, another $100 \mathrm{ml}$ were filtered sequentially through 20, 2 and $0.2 \mu \mathrm{m}$ nominal pore size polycarbonate filters (Millipore). In both cases, filtrations were carried out at low vacuum pressure ( $<100 \mathrm{~mm} \mathrm{Hg}$ ), and filters were frozen in the dark until analysis. Pigments were extracted in $3 \mathrm{ml}$ of $90 \%$ acetone for $24 \mathrm{~h}$ in the dark at $4^{\circ} \mathrm{C}$. Total and size-fractionated concentrations of chl a were determined spectrofluorometrically (Perkin Elmer LB-50s) (Neveux \& Panouse 1987).

Phototrophic pico-plankton within the size range 0.2 to $3 \mu \mathrm{m}$ in equivalent spherical diameter (ESD) was analysed from $1.8 \mathrm{ml}$ water samples previously fixed with $1 \%$ paraformaldehyde plus $0.05 \%$ glutaraldehyde solution, deep-frozen in liquid $\mathrm{N}_{2}$ and stored at $-70^{\circ} \mathrm{C}$ until analysis, with the abundance and size of picoplanktonic cells being determined by flow cytometry (FACSalibur, Becton \& Dickinson). After analysis, cells found in the cytograms were separated into 5 categories according to side-scattered light (SSC) and emitted fluorescence properties (FL2, $585 \mathrm{~nm}$ and FL3, >650 nm) (Olson et al. 1993): Synechococcus and Prochlorococcus cyanobacteria, 2 groups 
of eukaryotic cells, defined according to their SSC signal as 'small' and 'large' eukaryotes, and cryptophytes. Mean cell diameters of the different groups were obtained after sequential filtration through polycarbonate filters ranging from 0.2 to $3.0 \mu \mathrm{m}$ pore size (Zubkov et al. 1998). A spherical shape was assumed for all groups. Biomass was finally calculated applying volume-to-carbon conversion factors (Worden et al. 2004). A detailed description of the flow cytometry methods that were applied can be found elsewhere (Calvo-Díaz \& Morán 2006).

Phototrophic nano- and micro-plankton within the size range 5 to $100 \mu \mathrm{m}$ in ESD were analysed by means of the Flow Cytometer and Microscope (FlowCAM) from $1.1 \mathrm{l}$ water samples, which were kept fresh in the dark until analysis in the laboratory within a few hours after collection. Details of FlowCAM design and image acquisition procedures are available in Sieracki et al. (1998). Samples were processed in fluorescence-triggered mode, by means of which only those particles emitting red fluorescence (PMT1, $>650 \mathrm{~nm})$ when excited by a blue laser fan $(488 \mathrm{~nm})$ are photographed. Samples were split into 2 subsamples, 1 for nano-plankton and the other for microplankton size-fractions. The nano-plankton aliquot was pre-filtered by a $53 \mu \mathrm{m}$ mesh and processed unconcentrated, pouring $1 \mathrm{ml}$ of sample into the sample inlet and using a FC50-200x flow chamber-lens combination. For micro-plankton, 11 was pre-filtered through $200 \mu \mathrm{m}$ mesh and concentrated down to around $20 \mathrm{ml}$ by reverse filtration (Dodson \& Thomas 1978) through a $15 \mu \mathrm{m}$ net. Ten $\mathrm{ml}$ of this subsample were processed using an FC100-100 × flow chamberlens combination. The instrument was cleaned with distilled water between subsamples and a $2 \%$ bleach solution at the end of the day (maximum 10 samples). The application of the described sample-processing protocol provides reliable estimates of abundance in the ESD range of 5 to $100 \mu \mathrm{m}$ (Álvarez et al. 2011). The images provided by the FlowCAM were automatically classified as described by Álvarez et al. (2012) to discriminate among different categories (nano-eukaryotes, diatoms, silicoflagellates, dinoflagellates, ciliates and micro-eukaryotes) and remove detritus from the analysis. Particle biovolume $\left(\mu^{3}\right)$ was calculated as a revolution volume according to the shape of the particles and the dimensions (length and width) measured by image analysis. Biovolume was converted to carbon according to the functional group predicted, applying different conversion factors for cells smaller

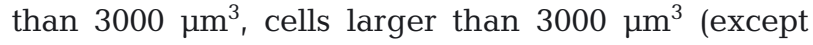
diatoms) and diatoms larger than $3000 \mu^{3}$ (MendenDeuer \& Lessard 2000).

\section{Data analysis}

The normalized biomass size spectrum (NBSS) is a structural representation of the plankton community (Rodriguez \& Mullin 1986) whose slope indicates the relative contribution of each size class to the total phytoplankton community. The 3 phytoplankton subsamples corresponding to the pico- (analysed by flow cytometry), nano- and micro-plankton size fractions (both analysed by FlowCAM) were combined to produce NBSS. For this, the biomass $\left(\mathrm{mg} \mathrm{C} \mathrm{m}^{-3}\right)$ of each cell was assigned to biovolume classes established on an octave $\left(\log _{2}\right)$ scale (from $2^{-8}$ to $2^{18} \mu \mathrm{m}^{3}$ in biovolume, which is equivalent to a size range from 0.2 to $100 \mu \mathrm{m}$ ESD) and aggregated. Only those biovolume classes with statistically reliable counts ( $>5$ counts per biovolume class) and to the left of the modal class (García et al. 1994) were considered. The biomass size spectra obtained in this way were normalized by dividing the biomass in each biovolume class by the width of the class. Since the 2 variables, biovolume and biomass per biovolume class, were measured with error, a reduced major axis regression model was fitted to the log-log transformed data to estimate the parameters, slope and intercept, of the NBSS.

We used the parameters of the linear regressions fitted to the NBSS to estimate biomass in specific size ranges by integrating the area under the fitted linear function within this size range. This procedure has the advantage of minimizing the effect of missing bins or bins deviating from linearity. Biomass was integrated in 3 size fractions, pico- $(0.2-2 \mu \mathrm{m})$, nano$(>2-20 \mu \mathrm{m})$ and micro-phytoplankton $(>20-200 \mu \mathrm{m})$, for which size-fractionated chl a was also determined. The ratio between chl $a$ and carbon biomass (chl a:C ratio), which represents an index of phytoplankton acclimation to different growth irradiances (Geider 1987), and the ratio between chl $a$ and biovolume (chl a:BV ratio) were estimated for the total autotrophic community and for each size fraction.

From the in situ PAR profiles, the attenuation coefficient $\left(k_{d}\right)$ for each day was estimated by linearization of the light extinction equation,

$$
E_{z}=E_{0} \times \mathrm{e}^{z \times k_{d}}
$$

where $E_{\mathrm{z}}$ and $E_{0}$ represent irradiance at a given depth and at the surface, respectively, and $z$ is the depth in the water column. Surface PAR on an hourly basis was recorded at a meteorological station located on land near the sampling area. The daily profiles of irradiance were estimated from the average surface solar radiation during the light hours and assuming a constant $k_{d}$. To estimate the history of 
irradiance for each sample, irradiance at the depth of the sample was estimated in the $24 \mathrm{~h}$ prior to the sampling hour (only light hours). The irradiance values were weighted taking into account the elapsed time and averaged.

The dependency of chl a:C on light can be modelled as an exponential function using irradiance as the independent variable (Cloern et al. 1995, Behrenfeld et al. 2002) for a range of growth conditions,

$$
\begin{aligned}
& \text { Chla:C }= \\
& \qquad \operatorname{chla}: C_{\min }+\left[\operatorname{chl} a: C_{\max }-\operatorname{chl} a: C_{\min }\right] \times \mathrm{e}^{-c E_{z}}
\end{aligned}
$$

where chl $a: C$ is the chl a to carbon ratio of the sample (mg chl $a \mathrm{mg}^{-1} \mathrm{C}$ ), chl a: $\mathrm{C}_{\max }$ is the low-light maximum, chl $a: \mathrm{C}_{\min }$ is the light-saturated minimum, $E_{z}$ is the irradiance level at the sampled depth $z$, and $C$ is the slope of the exponential decaying function that relates pigment content with light. Chl a: $\mathrm{C}_{\max }$ and chl a: $\mathrm{C}_{\min }$ decrease with temperature $(\mathrm{T})$ stress and nutrient $(\mathrm{N})$ limitation, respectively. Hence, the maximum values of both parameters describe the specific case of Eq. (2) without T stress or $\mathrm{N}$ limitation. This function is called chl a: $\mathrm{C}_{\mathrm{N}, \mathrm{T}-\max }$ and accounts for the maximum potential community chl $a$ :C as a function of light for optimal growth conditions. Since chl a: $\mathrm{C}_{\mathrm{N}, \mathrm{T}-\max }$ is a maximum potential function, it is estimated from parameterization of Eq. (2) as the function that envelopes a high proportion of the data $(80 \%)$. We derived values for the parameters using field measurements of chl a:C, light and Eq. (3):

$$
\text { Chla: } C_{\mathrm{N}, \mathrm{T}-\max }=a+b \times \mathrm{e}^{-c E_{Z}}
$$

Chl a:C values were split into classes defined by $E_{\mathrm{z}}$ intervals of $0.5 \mathrm{~mol}$ photons $\mathrm{m}^{-2} \mathrm{~h}^{-1}$ and the $80^{\text {th }}$ percentile of each class was estimated. The use of percentile bins was chosen in order to simultaneously apply a robust and a quantile regression (VázquezDomínguez et al. 2013) to the fitting models. For the whole community chl a:C values, a nonlinear model that uses the Levenberg-Marquardt fitting algorithm (Elzhov et al. 2015) was fitted to the resultant bins to obtain the slope of the exponential decaying function $(c)$. Then, for each size fraction, and using the $c$ value obtained previously, a linear model was fitted to the resultant bins to obtain the chl $a: \mathrm{C}_{\min }(a)$ and the difference between chl $a: \mathrm{C}_{\max }$ and $\mathrm{chl} a: \mathrm{C}_{\min }(b)$. The same procedure was followed with the ratios of chl a per unit of biovolume (chl a:BV).

To explore the variations of the main variables in the water column, we used 2-dimensional contour graphs of time ( $x$-axis) versus depth ( $y$-axis), with isoclines representing the represented variable. As the data points were irregularly spaced, we performed a bivariate interpolation onto a regular grid (Akima 1978).

\section{RESULTS}

\section{Seasonal context}

Hydrographical conditions showed the characteristic seasonality of a northern temperate shelf area, defined by the alternation of a thermally stratified period from May to October and a well-mixed period from December to March, with transitional phases in spring and autumn (Fig. 1a). The MLD ascended sharply from the bottom $(110 \mathrm{~m})$ to $30 \mathrm{~m}$ during the spring transition, remained between 20 and $40 \mathrm{~m}$ during the summer stratified period and descended gradually down to the bottom between the autumn transition and early winter (Fig. 1a). The level of underwater PAR (averaged daily) also exhibited 2 contrasting phases, with higher irradiance levels during the thermally stratified period than during the wellmixed and transitional periods (Fig. 1b). The seasonal variation of nutrients (exemplified by nitrate in Fig. 1c) was modulated by the annual cycles of hydrographical conditions and phytoplankton production. The surface concentration of nutrients decreased to minimum levels during the spring bloom (both in April 2008 and 2009). In 2008, the nitracline depth $\left(z_{\mathrm{N}}\right.$, proxy for the nutricline depth due to high covariation among inorganic nutrients) deepened down to $60 \mathrm{~m}$ and remained below $40 \mathrm{~m}$ during the stratified period. The vertical gradient of nutrients relaxed in early autumn, and subsequent winter mixing caused the replenishment of the surface nutrient pool in February 2009.

The annual evolution of the autotrophic community was coupled with the seasonality of the hydrographic scenario. The increment of PAR and surface temperature during the spring transition caused the deepening of $z_{\mathrm{eu}}$ and the ascent of the MLD $\left(z_{\mathrm{eu}}\right.$ :MLD ratio $>1$ ), favouring the retention of phytoplankton cells and their growth in the well-lit, nutrient-enriched surface layer. The spring bloom was dominated by large or medium-sized phytoplankton, which translated into size spectra with relatively flatter slopes (Fig. 1d). At the end of spring, concurrent with the exhaustion of nutrients, the spring bloom decayed (Fig. 1e). During the stratified period, autotrophic production took place at the level of the nutricline in the subsurface, where nutrients and light were sufficient to support growth, and a subsurface chl a max- 

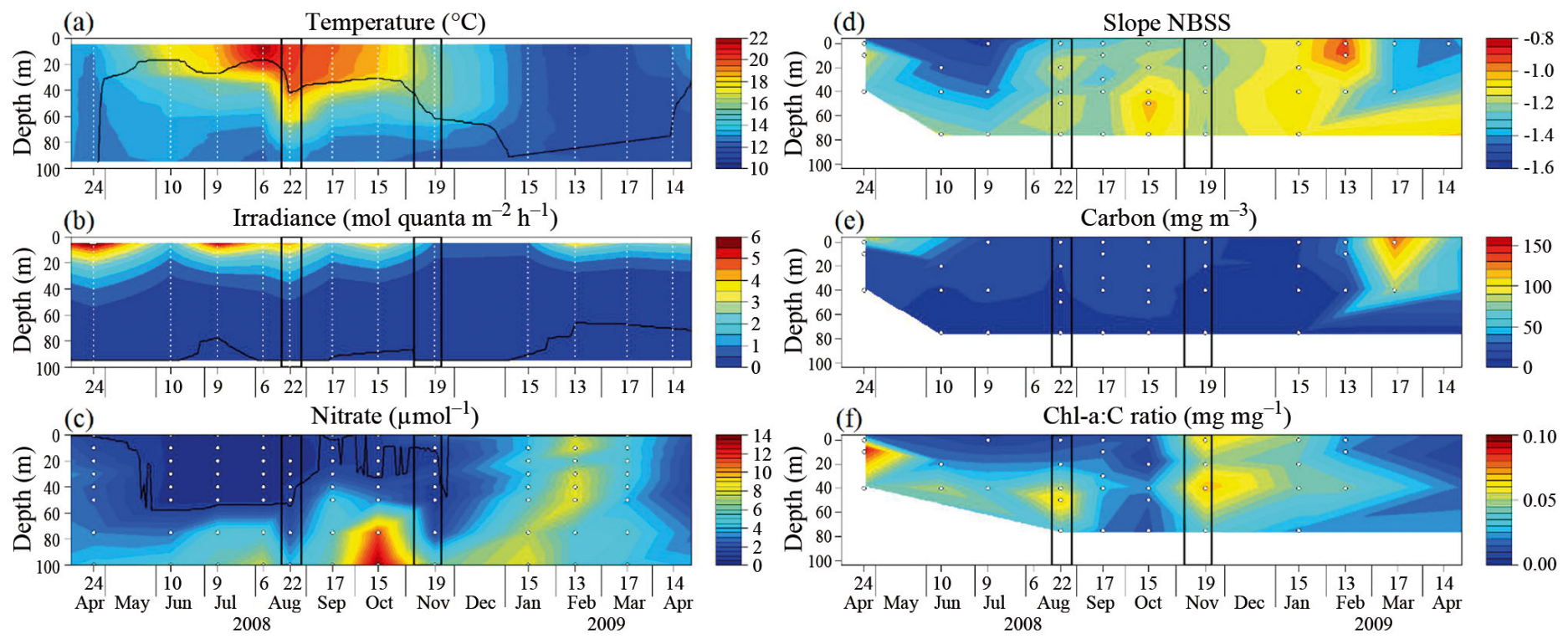

Fig. 1. Time-depth contours of physical and biogeochemical variables during a whole year. $x$-axes show the day and month of sampling. (a) Temperature and mixed layer depth (MLD); (b) photosynthetically active radiation (PAR) and euphotic depth $\left(z_{\text {eu }}, 1 \% \text { PAR }\right)_{;}(\mathrm{c})$ nitrate and depth of the nitracline $\left(z_{\mathrm{N}}, 1 \mu \mathrm{mol} \mathrm{l} \mathrm{l}^{-1}\right.$ isocline); (d) slope of the normalized biomass size spectra (NBSS); (e) total carbon biomass; (f) chl a to carbon ratio. Black boxes indicate the dates of the intensive cruises in August and November 2008

imum developed $\left(z_{\mathrm{CM}}\right.$ at $\left.40 \mathrm{~m}\right)$. The dominance of small cells in these nutrient-poor conditions translated into steeper size spectra (i.e. lower slope values). The stratified period was characterized by relatively low chl a:C ratios, with an increase in the chl a:C ratio with depth (Fig. 1f). Deepening of the MLD during the autumn transition supplied nutrients to the surface, boosting primary production in this layer and the development of the autumn bloom. The autumn bloom was characterized by flatter size spectra (i.e. higher slope values) and with the autotrophic community being characterized by high $\mathrm{chl}$ a: $\mathrm{C}$ ratios with a narrow range of vertical variation. Winter was the season with the lowest biomass, probably due to light limitation $\left(z_{\mathrm{eu}}\right.$ :MLD ratio $\left.<1\right)$.

\section{Short-term dynamics during summer stratification and autumn transition}

Hydrographical conditions during the summer survey were characterized by strong thermal stratification (difference in surface to bottom temperature of $10^{\circ} \mathrm{C}$ ) and the ascent of the MLD from $40 \mathrm{~m}$ at the beginning of the cruise to $20 \mathrm{~m}$ towards its end (Fig. 2a). Underwater PAR levels within the MLD were high during the whole survey: surface values reached $5 \mathrm{~mol}$ photons $\mathrm{m}^{-2} \mathrm{~h}^{-1}$, and $z_{\text {eu }}$ remained below $100 \mathrm{~m}$ (Fig. 2b). The opposite trends of MLD and $z_{\mathrm{eu}}$ resulted in the increment of the $z_{\text {eu }}$ :MLD ratio from 2 to
5. The concentration of nutrients showed a sharp vertical gradient. Nitrate was below detection limits at the surface, except for a short period during the first 2 sampling days, and reached maximum concentrations at the bottom (around $9 \mu \mathrm{mol} \mathrm{l}^{-1}$ ). The nitracline deepened from $20 \mathrm{~m}$ at the beginning of the cruise to a maximum of $60 \mathrm{~m}$ on 23 August (Fig. 2c), rising from this depth to the surface during the following days driven by an upwelling event (Fig. 2a,c).

The concentration of autotrophic carbon biomass was low at all depths, with a larger contribution of pico-, and to a lesser extent nano-, size fractions, which translated into steeper and relatively constant size spectra slopes $(-1.26 \pm 0.08 \mathrm{SD})$ during the whole period (Fig. 2d). Relatively high carbon biomass values (mean and maximum values of $13.3 \pm 6.98$ and $31.7 \mathrm{mg} \mathrm{C} \mathrm{m}^{-3}, \mathrm{n}=24$ ) occurred not only in the subsurface but also at the surface. The pattern of chl a distribution differed from that of autotrophic carbon biomass, since total chl a during the summer survey reached maximum values only in the subsurface. The discrepancies between chl $a$ and carbon biomass fields translated into the variability of the $\mathrm{chl} a$ :C ratio (average value of $0.025 \pm 0.018, \mathrm{n}=24$; Fig. 2 e) which increased with depth, reflecting the acclimation of the pigment content of phytoplankton cells to progressively decreasing light levels.

During the autumn transition, the MLD fluctuated between 50 and $80 \mathrm{~m}$. Temperature within the mixed layer was almost homogeneous (Fig. 2f), and thermal 


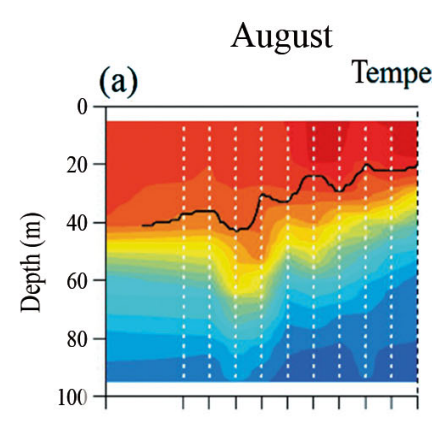

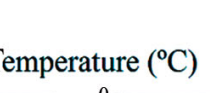

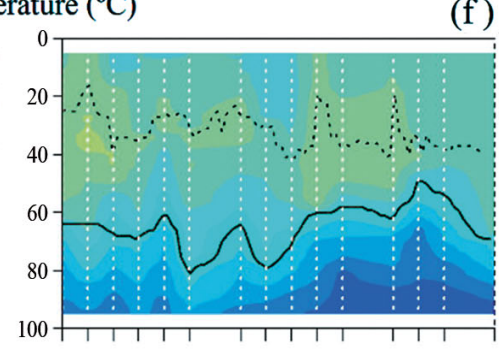

(f)

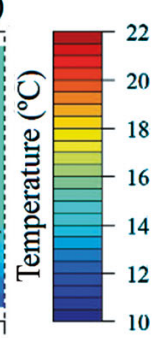

(b)

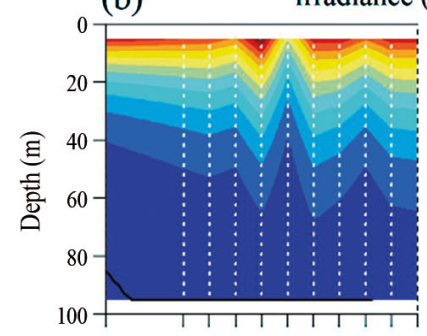

\begin{abstract}
(mol quanta $\mathrm{m}^{-2} \mathrm{~h}^{-1}$ )
\end{abstract}
(g)
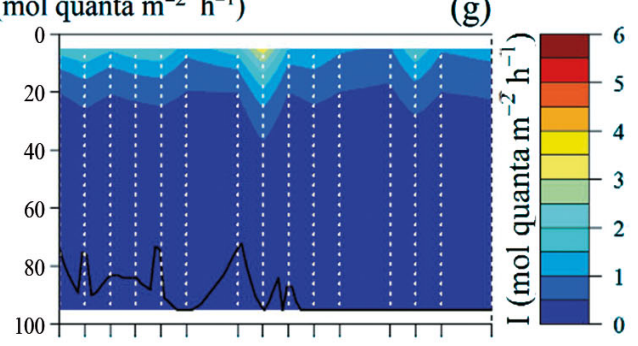

(h),

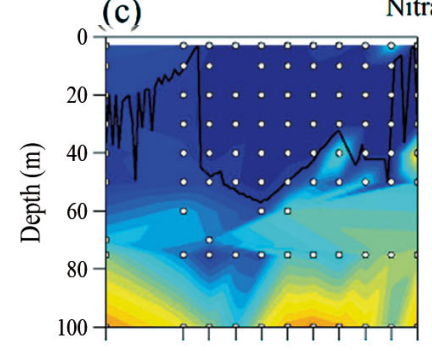

Nitrate $\left(\mu \mathrm{mol} \mathrm{l}{ }^{-1}\right)$
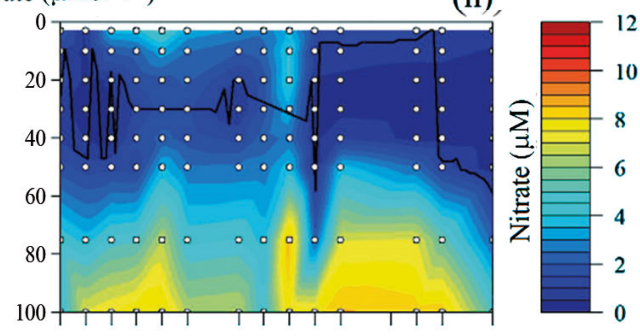

(d)

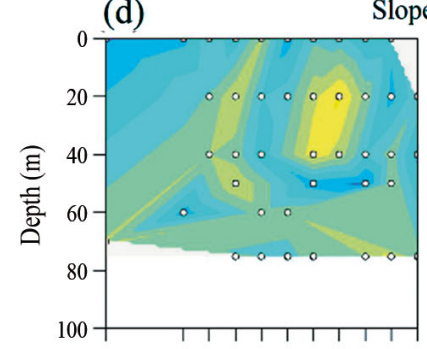

ope NBSS

(i)
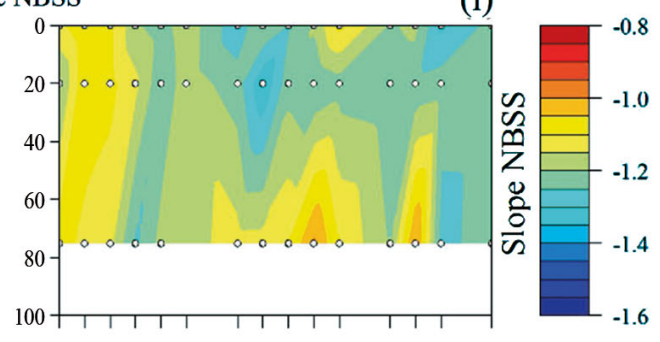

(e)
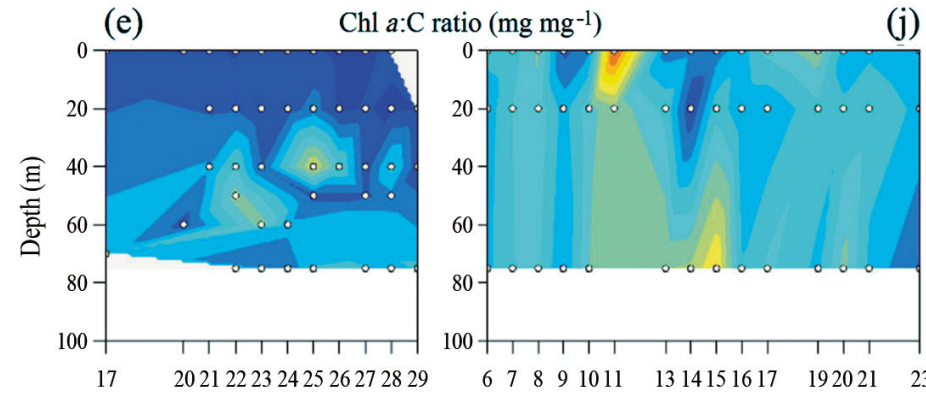

(j)

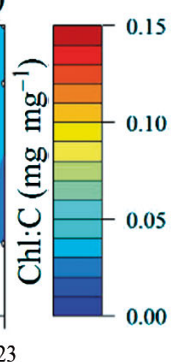

Fig. 2. Time-depth contours of physical and biogeochemical variables during intensive cruises carried out in August (left panels) and November (right panels): $(\mathrm{a}, \mathrm{f})$ temperature and mixed layer depth (MLD; dotted line indicates thermal inversion); (b,g) photosynthetically active radiation (PAR) and euphotic depth $\left(z_{\text {eu }}, 1 \%\right.$ PAR $) ;(\mathrm{c}, \mathrm{h})$ concentration of nitrate $\left(\mu \mathrm{mol} \mathrm{l}^{-1}\right)$ and depth of the nitracline $\left(z_{\mathrm{N}}, 1 \mu \mathrm{mol} \mathrm{l} \mathrm{l}^{-1}\right.$ isocline); (d,i) slope of the normalized biomass size spectra (NBSS); (e,j) chl a to carbon ratio inversion was caused by moderate precipitation just before and during the survey. Daily averaged solar radiation was significantly lower than in August, with maxima of $3.5 \mathrm{~mol}$ photons $\mathrm{m}^{-2} \mathrm{~h}^{-1}$ at the beginning of the sampling and decreasing to less than 1.5 mol photons $\mathrm{m}^{-2} \mathrm{~h}^{-1}$ towards the end. Although underwater irradiance levels at noon decreased sharply in the first $10 \mathrm{~m}$ of the water column, the euphotic zone still ranged from 75 to $100 \mathrm{~m}$, with $z_{\mathrm{eu}}$ :MLD ratios from 1.5 to 1 (Fig. 2g). The vertical gradient of nutrients persisted during the studied period, although it was less intense than in August and was eroded several times due to successive surface nutrient enrichment episodes associated with runoff pulses, causing $z_{\mathrm{N}}$ to oscillate between $40 \mathrm{~m}$ and the surface (Fig. 2h).

Maximum carbon biomass values were marginally higher (Student's $t$ test on mean values, $p=0.0854$ ) in autumn than in summer and were observed in the surface (mean and maximum values of $20.0 \pm 13.09$ and $52.0 \mathrm{mg} \mathrm{C} \mathrm{m}{ }^{-3}, \mathrm{n}=15$ ). Total phytoplankton biomass distribution showed a marked vertical gradient, with surface peak values of $50 \mathrm{mg} \mathrm{C} \mathrm{m}^{-3}$ associated with plumes and increased biomass within the MLD towards the end of the study period. Despite the variability of total biomass, the partitioning of carbon among size fractions remained relatively constant during the whole period, summarised by flatter, nearly constant $(-1.18 \pm 0.08)$ NBSS slopes (Fig. 2i). The average chl $a$ :C ratios $(0.046 \pm 0.020, \mathrm{n}=44)$ were significantly higher (Student's t-test on mean values, $\mathrm{p}<0.0001$ ) than in summer (Fig. 2j) and increased weakly with depth. The high chl a:C ratios reflected the acclimation of the community to reduced solar radiation levels during autumn, and the diminished difference between surface and bottom ratios reflected the mixing regime that the phytoplankton cells experienced during this period. 


\section{Decoupling of biovolume/carbon and chl a}

We observed an association between the variability of the slope of the NBSS and nitrate concentrations, especially at the seasonal scale (Fig. 1c,d). To evaluate the role of nutrients, temperature and light as potential drivers of the variability of the NBSS slope, we ran a generalized linear model (GLM). Results indicated that nitrate concentration had an effect on the slope of the NBSS ( $p=0.0006, n=120)$, but the interaction between nitrate and temperature was also significant (GLM interaction, $\mathrm{p}=0.0020, \mathrm{n}=$ 120). Hence, it is not possible to efficiently correct the relationship between nutrients and temperature due to co-linearity between both variables, since temperature is an indicator variable of other processes that are driving the observed variability in nutrients, i.e. coastal upwelling-downwelling events and mixingstratification cycles. If the size structure varies prima-
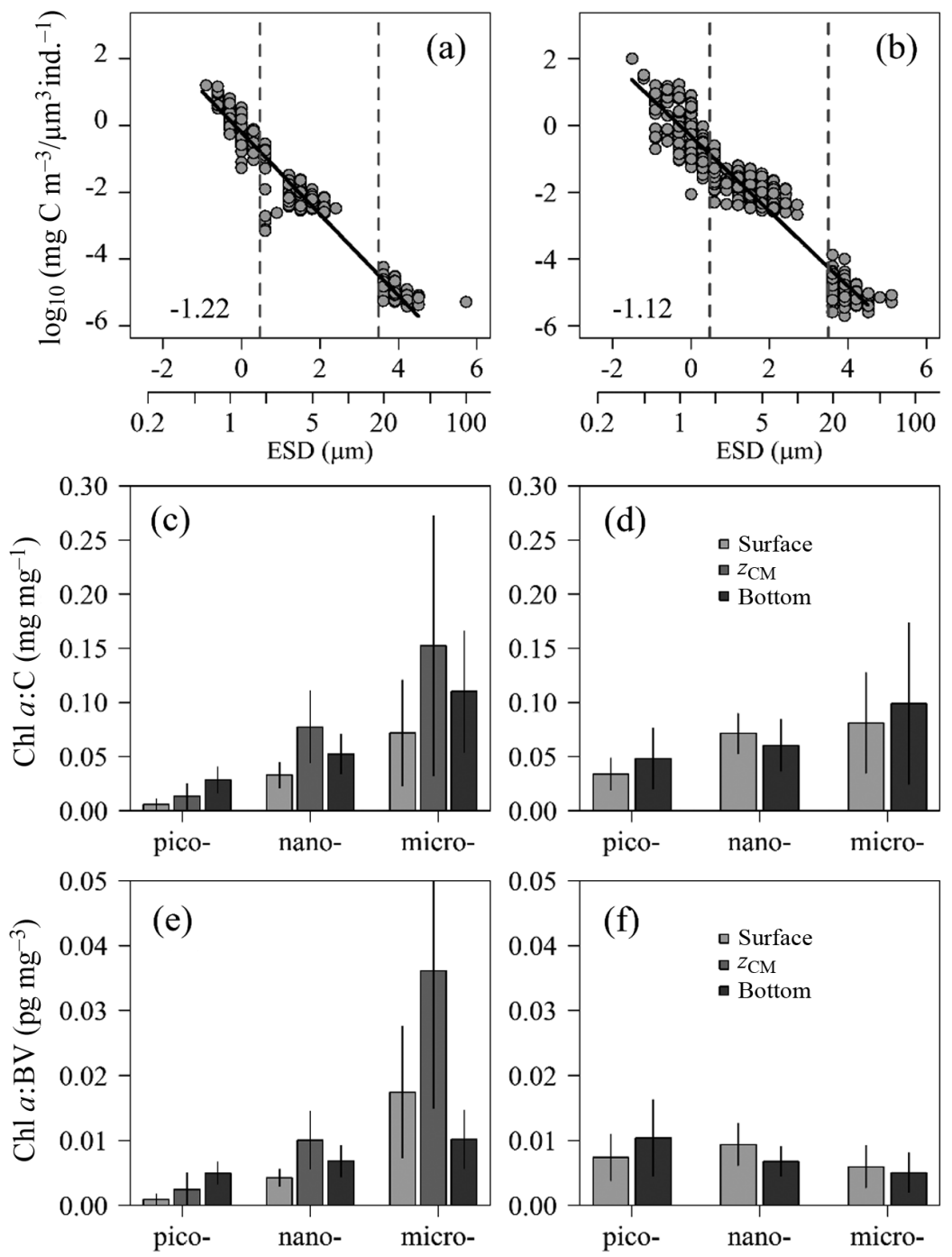

rily with nutrient content, cell size must be considered when exploring the variability of chl a content in natural conditions, otherwise observed changes in chl a:C can be driven by cell size instead of temperature, nutrients, light or taxonomic composition. To account for the effect of variation of taxonomic composition on the chl a:C ratio, we analysed the correlation between the chl a:C ratio found for the picoplankton and the ratio between the biomasses of Prochlorococcus and Synechococcus ( $\mathrm{p}=0.2256, \mathrm{n}=$ 151), and between the chl a:C ratio found for the micro-plankton and the ratio between the biomasses of diatoms and dinoflagellates ( $\mathrm{p}=0.3477, \mathrm{n}=126)$. Since both correlations were not statistically significant, the taxonomic composition was excluded as a main factor driving the variability of chl a:C ratios.

We explored the effect of light and mixing regime on the chl a:C ratio per size fraction (Fig. 3). Given the oligotrophic conditions in summer, the functional groups that contributed most to carbon biomass were eukaryotic pico- and nano-phytoplankton, with micro-phytoplankton being considerably less abundant. The parameters of the NBSS therefore remained relatively constant during August, and the global spectra for the period had a slope of -1.24 (Fig. 3a). In autumn, on the other hand, the whole community contributed to the increase in biomass, and micro-plankton was more abundant than in the summer, reflecting a relative increment of larger cells. Although the increment of biomass took place in the form of pulses on 9, 14 and 20 November, the NBSS remained relatively constant during November with slopes flatter than in August; the global spectra had a slope of -1.13 (Fig. 3b; ANOVA interaction, $\mathrm{p}<0.0001, \mathrm{n}=739$ ).

Fig. 3. Global normalized biomass size spectra of phytoplankton for all samples taken during intensive cruises carried out in (a) August and (b) November. For the 3 size fractions and 3 different depths of the water column, chl a to carbon ratio in (c) August and (d) November and chl a $\mu \mathrm{m}^{-3}$ of cell biovolume (BV) in (e) August and (f) November are shown. $z_{\mathrm{CM}}$ : subsurface chl a maximum; ESD: equivalent spherical diameter 
During the summer, when irradiance and temperature peaked, the water column was strongly stratified and inorganic nutrient concentrations were low at the surface, phytoplankton chl a to carbon ratios presented minimum values at the surface $(0.0058 \pm$ 0.0048) whereas the values increased at the chl $a$ maximum depth $(0.0273 \pm 0.0128)$, reaching maximum values at the bottom of the water column $(0.0337 \pm 0.0079)$. The discrepancies between chl $a$ and carbon biomass fields in summer were due to the variability of the chl a:C ratio (Fig. 3c), which increased with depth, reflecting the acclimation of the pigment content of phytoplankton cells to progressively lower light levels. Pico-phytoplankton in general had lower (0.0159 for pico-, 0.0542 for nanoand 0.1114 for micro-phytoplankton, Student's $t$ test, $\mathrm{p}=0.0150, \mathrm{n}=94$ ) and less variable chl $a$ :C ratios (see error bars in Fig. 3c,d) at all depths than the nano- and micro- size-fractions, although the differences in chl a:C ratios among the autotrophic components diminished from the surface to the bottom (Fig. 3c). The pattern shown by the chl $a$ per unit of cell biovolume was very similar $(0.0028$ for pico-, 0.0071 for nano- and 0.0213 for microphytoplankton), but the differences in chl a:BV ratios were not significant between size fractions (ANOVA, $\mathrm{p}=0.3927, \mathrm{n}=99$; Fig. 3e).

Conversely, intermediate ratios were reached during autumn $(0.0414 \pm 0.0129$ at the surface, $0.0499 \pm$ 0.0206 at $75 \mathrm{~m}$ depth), coincident with lower irradiance but maximum concentration of inorganic nutrients in the whole water column. The average chl a:C ratios of the autotrophic community at the surface were significantly higher in autumn (Student's $t$-test, $\mathrm{p}<0.0001, \mathrm{n}=26$ ) than in the summer (Fig. 3d). Although the ratios also increased with depth, the vertical gradient was not so sharp and the values were not significantly different for the 3 size fractions (0.0409 for pico-, 0.0658 for nano- and 0.0901 for micro-phytoplankton, Student's $t$-test, $\mathrm{p}=$ $0.0669, \mathrm{n}=90)$. The high $\mathrm{chl}$ a: $\mathrm{C}$ ratios reflected the acclimation of the community to reduced solar radiation levels during autumn, and the diminished difference between the surface and bottom ratios reflected the mixing regime that the phytoplankton cells experienced during this period (Fig. 3d). The chl a per unit of cell biovolume was not comparatively different for the pico- than for the nano- and micro-phytoplankton components $(0.0089$ for pico-, 0.0081 for nano- and 0.0055 for micro-phytoplankton, ANOVA $\mathrm{p}=0.1566, \mathrm{n}=90$; Fig. 3f), indicating that the concentration of $\operatorname{chl} a$ was homogeneous between size classes.

\section{Size scaling of photoacclimation}

The complex effect of light, nutrients and temperature leads to a variable chl a: C ratio in phytoplankton cells. The relationship between chl a: $\mathrm{C}$ and light for a range of growth conditions has a low-light maximum that varies proportionally with temperature and a light-saturated minimum that varies proportionally with nutrient availability (Eq. 2) (Behrenfeld et al. 2005). The slope of this decaying function was, for the whole phytoplankton community, $-0.25 \pm 0.83$ for chl a:C and $-0.27 \pm 0.39$ for chl a:BV. In Fig. 4, chl a:C and chl $a: B V$ for each size fraction were plotted against field irradiance levels and the chl a: $\mathrm{C}_{\mathrm{N}, \mathrm{T}-\max }$ and chl a:BV $\mathrm{N}_{\mathrm{N} \text { T-max }}$ adjusted with Eq.(3) and the slope estimated previously for the whole community. Picophytoplankton in general had lower chl a:C ratios at all depths than the nano- and micro- size fractions and hence the chl a: $\mathrm{C}_{\mathrm{N} \text {,T-max }}$ functions scaled accordingly (Fig. $4 \mathrm{a}-\mathrm{c}$ ). Mean values of $\mathrm{chl} a: \mathrm{C}_{\min }$ and chl a: $\mathrm{C}_{\max }$ varied for the 3 size fractions $(0.005$ and 0.052 for pico-, 0.033 and 0.093 for nano-, 0.055 and 0.147 for micro-phytoplankton, respectively). Given the allometric relationship between carbon biomass and cellular biovolume, the size dependence of chl a content per biovolume unit was minimally attenuated over the size classes (0.001 and 0.011 for pico-, 0.005 and 0.012 for nano- and 0.010 and 0.016 for micro-phytoplankton; Fig. 4d-f). Since chl a content per biovolume unit is a more direct estimate of intracellular chl a concentration, we decided to use the chl a:BV ratio to directly discriminate the photoacclimation processes.

The range of variability between the maximum and minimum chl a:BV ratio or, which is the same, chl a concentration, was different for each size fraction, with the smaller cells showing greater variation (Fig. 5a). Hence, photoacclimation through the variation of the chl a concentration was size dependent. To understand the implications of this size-dependent range of variability of chl a content on the size scaling of the photoacclimation, we made a series of predictions with the parameters of the chl a:BV $\mathrm{BV}_{\mathrm{N}, \mathrm{T}-\mathrm{max}}$ functions obtained. The $3 \mathrm{chl} a: \mathrm{BV}_{\mathrm{N}, \mathrm{T}-\mathrm{max}}$ functions were used to predict the chl a:BV for each size fraction for a sequence of irradiances (Fig. 5b). The relationship between chl a:BV and the lower biovolume limit of the size fraction on a log-log scale shows the size scaling of chl a content. The exponent of the size scaling of chl a:BV for each irradiance level was obtained with a reduced major axis model. The exponent of the size scaling increased with increasing irradiance (Fig. 5c). 

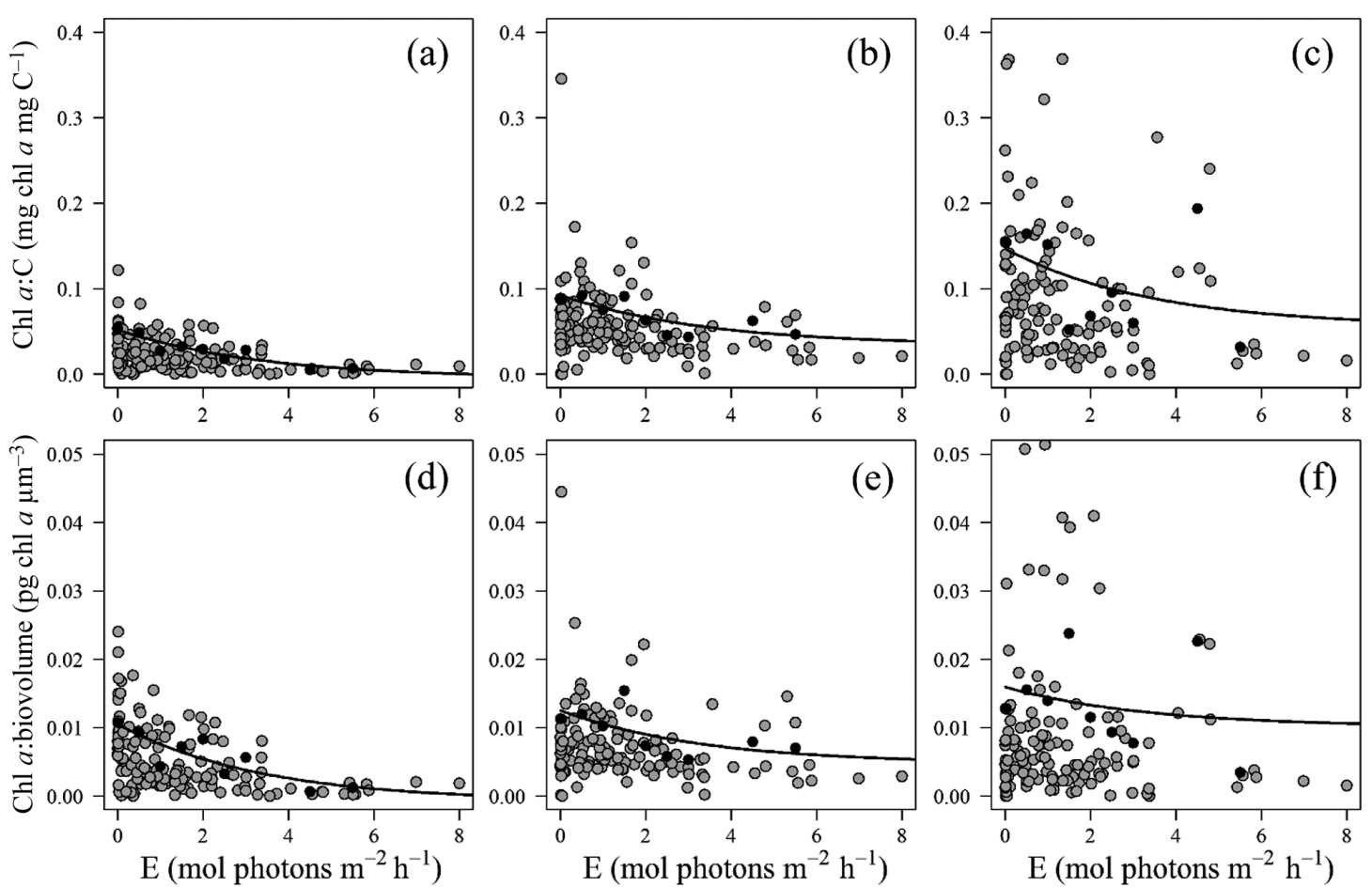

Fig. 4. Changes in phytoplankton pigment content in response to changes in the light field: (a-c) chl a to carbon ratio (mg chl a $\mathrm{mg}^{-1} \mathrm{C}$ ) and (d-f) chl a per biovolume (BV) unit (pg chl $a \mathrm{~mm}^{-3}$ ) as a function of irradiance $(E)$ at the sampling depth for the pico-, nano- and micro-phytoplankton size fractions, respectively. Solid line denotes the chl a: $\mathrm{C}_{\mathrm{N}, \mathrm{T}-\max }$ (in panels a-C) and chl a:BV $\mathrm{B}_{\mathrm{N}, \mathrm{T}-\max }$ (in panels $\mathrm{d}-\mathrm{f}$ ) functions fitted to the $80^{\text {th }}$ percentile of the ratio in each irradiance class (black dots). See 'Materials and methods' for details
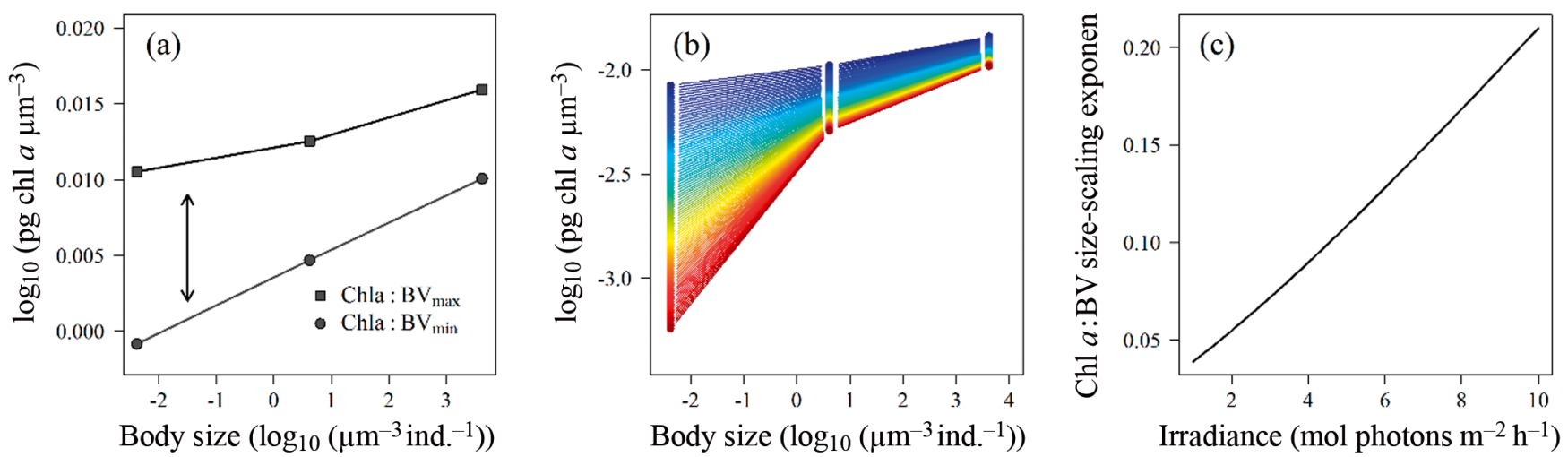

Fig. 5. Size-dependence of photoacclimation: (a) parameters of the chl a:biovolume (BV) $)_{\mathrm{N}, \mathrm{T}-\mathrm{max}}$ function as a function of body size (see 'Materials and methods' for details), chl $a: B V_{\min }$ and chl a:BV $\max ($ (b) prediction of the size scaling of the intracellular chl a concentration for a sequence of irradiance values (the gradient from cold to hot colours corresponds to the gradient from low to high irradiances); (c) modelled variation of the size-scaling exponent of intracellular chl a concentration as a function of irradiance

\section{DISCUSSION}

The Bay of Biscay is a typical temperate ecosystem, and as such is characterized by strong seasonality of the water column mixing-stratification cycle (Fig. 1a). The spring to summer transition in the Cantabrian Sea is associated with a shift from coastal downwelling to upwelling conditions (Fernández \& Bode 1991) (Fig. 1c). The general circulation in the Bay of Biscay is anticyclonic (Pingree \& LeCann 1990), although the hydrodynamics along the northern and western Iberian shelf are also affected by the presence of subtropical and saline waters transported by the Iberian Poleward 
Current (Peliz et al. 2005) from late autumn to early spring.

The seasonal scale addressed in this work allowed us to cover an ample range of oceanographic conditions. We have described the characteristic seasonality of the hydrographical conditions in a temperate continental shelf. Phytoplankton physiology and production were highly influenced by hydrographical conditions, and hence the abundance of phytoplankton cells followed a strong seasonal cycle (Fig. 1d) (Calvo-Díaz et al. 2008). Variability in phytoplankton biomass distribution and standing stocks appeared related to the MLD, $z_{\mathrm{eu}}$ and $z_{\mathrm{N}}$, and the absolute levels of temperature, light and nutrients. The phytoplankton dynamics of the area were characterized by an annual maximum of phytoplankton biomass and production in late winter/early spring that can extend into the rest of the year with different intensity, contributing significantly to regional productivity (Álvarez et al. 2009, Morán \& Scharek 2015).

Phytoplankton dynamics were studied in detail during 2 stages of intensive sampling. The aim was to investigate the potential biological consequences of 2 contrasting chemical and hydrological scenarios. Summer was characterized by strong thermal stratification, depletion of nutrients within the surface mixed layer and deep light penetration (Fig. 2a-c), while autumn was characterized by mixing of the water column, replenishment of nutrients in the surface layer and low light levels in the whole water column (Fig. 2f-h). The daily sampling scale of the intensive surveys permitted a synoptic vision of the short-term variability of the dynamics of phytoplankton. The absence of nutrients in the surface layer during the summer period limited the phytoplankton biomass to the subsurface (Fig. 2d,e), where nutrients and light were sufficient to permit the growth of small cells, which are adapted for efficient harvesting of light and nutrient resources (Granda \& Anadón 2008). On the other hand, the increase in nutrients into the upper layer during November triggered a population abundance increase (Fig. 2i,j).

Beyond this descriptive output, the database presented in this work had the potential to explore the variations in the size scaling of pigment content in phytoplankton communities. Phytoplankton stock was measured both in terms of size/carbon and chl $a_{\text {, }}$ and those attributes were estimated for 3 size fractions. This allowed us to explore the variations in pigment content and size of the phytoplankton over a wide range of oceanographic conditions. The work led us to 3 conclusions: (1) Measurement of phytoplankton biomass both in terms of carbon and chl $a$ showed that the description of plankton dynamics differs using each proxy for plankton biomass. Hence, the use of the carbon to chl a ratio allowed us to explore not only the dynamics of the biomass stock but also the photoacclimation processes that had been taking place in the water column. (2) Estimating these proxies by size fractions allowed us to explore the different allometries of the carbon and the chl a per phytoplankton cell, which revealed a size dependence of the chl a content per unit of biomass. (3) Changes in the chl a content per size fraction as a function of field irradiance in individual samples demonstrated that the size scaling exponent of the chl a content varied with the irradiance level. The first 2 conclusions are not new, since the size scaling of pigment content has been observed in the laboratory (Key et al. 2010) and in the field (Marañón et al. 2007). However, the conclusion that the size scaling of pigment content varied with irradiance levels has not been reported previously in natural populations of marine phytoplankton.

The relationship between the phytoplankton carbon biomass and chl a concentration was non-linear owing to the complex, and presumably interacting, influences of light, nutrients and temperature in the euphotic zone. During the autumn survey, phytoplankton carbon and chl a were highly coupled, indicating that $\mathrm{chl} a$ is a good proxy for phytoplankton biomass (Fig. 3d), while during the summer, phytoplankton carbon and chl a were uncoupled, indicating that chl a concentration did not reflect phytoplankton biomass as precisely (Fig. 3c). It has been widely recognised that the description of a community can change substantially when using chl $a$ or biovolume/carbon as surrogate variables for phytoplankton biomass (Cullen 1982, Buck et al. 1996, Huot et al. 2007, Wang et al. 2013). The results presented in this study show the extent of this change in the temperate coasts of the North Atlantic.

The chl a:C ratios reflected the levels of light regime experienced by phytoplankton cells. Light was primarily responsible for the vertical increase in the phytoplankton chl a: $\mathrm{C}$ ratio in the euphotic zone, as a consequence of the water column stability in summer (Fig. 3c-e). The phytoplankton pigment content during the autumn survey was highly dependent on mixing events, which resulted in homogeneous chl a:C values with depth (Fig. 3d-f). In this situation of low light availability, chl a:C ratios were relatively high, thus allowing phytoplankton cells to harvest light efficiently even when drawn to deeper depths, and hence low light levels. Chl a:C ratios have been estimated for the whole autotrophic community and for 
specific components (Cermeño et al. 2005, VázquezDomínguez et al. 2013), in situ and even from space (Behrenfeld et al. 2005). The chl a:C ratios showed a large degree of variability, but the chl $a$ :C ratios obtained in this study fell in the range of those previously reported (Gutiérrez-Rodríguez et al. 2010) and followed trends similar to those demonstrated for other coastal and shelf realms (Buck et al. 1996, Cermeño et al. 2005). This fact, together with the expected observations of an increase in $\mathrm{chl}$ a:C ratios with depth during stratification, gave us further confidence in the validity of our estimates.

The second conclusion relies on the fact that both carbon and chl a were estimated for 3 size fractions, which allowed us to explore the allometry of both variables. Since the size structure of the phytoplankton community was driven by changes in temperature and nutrients (Irwin et al. 2006), the NBSS slopes estimated during August were lower than in November (Fig. 3a,b), reflecting a dominance of small cells in the oligotrophic conditions characteristic of summer and a relative increment of larger cells during autumn. However, this different proportion of size classes was not reflected in the chl a data. Hence, a size dependence of chl a content arose, shown by the uncoupling of carbon and chl a allometry. This size dependence has been observed in laboratory studies (Agustí 1991, Key et al. 2010) and in field studies based on the fractionation of chl a (Pérez et al. 2006, Marañón et al. 2007).

Although the chl a:C ratios showed a clear positive scaling with cell size, chl a:BV ratios showed weaker patterns (Fig. 4). This was due to the allometric relationship between carbon and biovolume that assigns lower carbon density to larger cells relative to smaller cells. We therefore propose that the concentration of chl a per unit of cellular volume is the appropriate parameter to account for the effects of photoacclimation, since the effects on the chl a content per unit of biomass could be magnified by the biovolume to carbon conversions.

The direct measurement of phytoplankton carbon biomass per individual cell is a challenging issue. Elemental analysis, after effectively separating phytoplankton from other carbon constituents, provides direct estimates of carbon (Graff et al. 2012). However, single-cell elemental analysis, despite its potential, is limited by the number of cells that can be analysed in a sample (Heldal et al. 2003). On a single-cell basis, carbon is still estimated from cell biovolume through microscopic measurement and flow cytometry. The estimation of carbon from biovolume depends on an accurate biovolume determination and a trust- worthy biovolume to carbon conversion. Since biovolume to carbon conversion is expected to be taxon specific, the use of a limited set of conversions is a necessary simplification.

Uncertainties also arose in this and other studies from the need to deal with the low resolution of the size fractions of chl a. Whereas flow cytometric techniques allow the enumeration and sizing of single cells, the data must be aggregated to compare with $\mathrm{chl}$ a fractionation, usually only undertaken for 3 size classes. Three size fractions are the minimum number necessary to explore the allometry, but, obviously, a larger number would increase the reliability of our estimates. Flow cytometric techniques based on fluorescence, such as flow cytometry and FlowCAM, open the scope to the interpretation of fluorescence signals and the use of these signals as a proxy of the chl a content in single cells (Sosik et al. 1989) as shown for pico-phytoplankton groups in the region (Calvo-Díaz et al. 2008). Although the lack of a calibration prevented us from using this approach, it appears that it may have considerable potential.

The chl a content per unit of carbon was lower in smaller cells, which is consistent with previous observations in the Mediterranean Sea and the equatorial Pacific (Arin et al. 2002, Le Bouteiller et al. 2003). However, this is opposite to what may have been expected based on the optimal packaging theory (Finkel et al. 2004). Since photoacclimation requires adequate nutrient supply (Herzig \& Falkowski 1989) and nutrient limitation influences the chl a concentration within the cell, this was interpreted as an indication of changing cellular chl a concentration in response to changing nutrient concentration. During the autumn survey, our results showed a negative, although not statistically significant, trend in size scaling in the chl a concentration, which may be due to the high concentration of nutrients in the water column (Fig. 3f). A decrease in nutrient availability has a negative effect on chl a concentration (Sakshaug et al. 1989, Cloern et al. 1995), hence the positive size-scaling of chl a content found frequently in the field may be consistent with smaller species being adapted to lower nutrient concentrations. Few laboratory studies have specifically investigated nutrient-dependent changes in the abundance of lightharvesting pigments, and generally, it is assumed that the relationship between light and chl $a$ is the same under nutrient-saturated or -depleted conditions (Behrenfeld et al. 2002). Our results suggest that this may not be the case, although further work is necessary to establish the role of nutrient status on the size dependence of chl a content. 
The main contribution of this work is the finding that light levels influence the size scaling of chl a content in situ, reflecting a different plasticity of photoacclimation per size class in the ocean, but to some extent consistent with laboratory observations and model predictions. The intensity of photoacclimation was size dependent, with the smallest cells showing larger variability in pigment content than larger cells. This has a geometric explanation, since the 'package effect' prevents larger cells from increasing their pigment content beyond the limits imposed by the surface to volume ratio. The model of Finkel et al. (2004) predicts resource acquisition as the main driver of the size scaling change, which was corroborated by laboratory data (Fujiki \& Taguchi 2002). However, the size scaling of chl a content from in situ sampling has been less explored. Few photoacclimation studies have been conducted with in situ data (Behrenfeld et al. 2008) and, as far as we know, this is the first time that variation in the size dependence of the chl a content with irradiance has been observed from field data.

There is a growing interest in the estimation of phytoplankton growth rates in the ocean given their relevance to our understanding of the global carbon cycle (Saux Picart et al. 2014). The size-dependent plasticity in the photoacclimation processes has consequences in relation to marine system productivity and carbon turnover. Photoacclimation allows photosynthetic gains to surpass respiratory losses farther down the water column than would be possible without photoacclimation, thereby pushing the euphotic depth deeper and increasing the duration of time allowing cell multiplication. Productivity models with explicit photoacclimation terms can improve the primary production predictions (Westberry et al. 2008). However, the extent of photoacclimation can be different depending on the size of the organisms, hence making necessary the joint consideration of photoacclimation and phytoplankton cell size in ocean productivity models. The variability of pigment content allometry as a function of light intensity has consequences in the estimation of productivity under the ocean surface. Results such as these demonstrated here provide a mechanistic basis for the development of size-resolved models for ocean primary production.

\section{CONCLUSIONS}

The size structure of the phytoplankton community in the southern Bay of Biscay appeared to be strongly influenced by the meteo-hydrological scenario, both over the short term and at seasonal scales. The variability of the chl a content in the phytoplankton community due to light acclimation and nutrient stress confounded the relationship between chl $a$ and phytoplankton biomass. The estimation of both attributes in natural samples permitted a better description of the dynamics of the phytoplankton community both in terms of biomass stock and photo-physiological processes. The size dependence of photoacclimation processes was observed in situ, and the increment of the size-scaling exponent with the increase in irradiance was derived from natural samples, as predicted by models and laboratory experimental data.

Acknowledgements. We thank the captain and crew of RVs 'Francisco de Paula Navarro' and 'José Rioja' and all participants in the cruises for their work and dedication at sea and in the laboratory. We also thank F. Ronzón, who kindly provided data from his meteorological station in Gijón/Xixón. This work was supported by the Ministerio de Ciencia e Innovación (project PERPLAN, 'Efecto de las perturbaciones meteorológico-hidrográficas en la estructura de la comunidad planctónica', CTM2006-04854/MAR), the Plan de Ciencia, Tecnología e Innovación del Gobierno del Principado de Asturias (project IMAGINA and research grant BP07-081 to E.A.), the Instituto Español de Oceanografía (project RADIALES) and the Principado de Asturias FEDER (GRUPIN14-144).

\section{LITERATURE CITED}

Agustí S (1991) Allometric scaling of light absorption and scattering by phytoplankton cells. Can J Fish Aquat Sci 48:763-767

Akima H (1978) A method of bivariate interpolation and smooth surface fitting for irregularly distributed data points. ACM Trans Math Softw 4:148-164

Álvarez E, Nogueira E, Acuña JL, López-Álvarez M, Sostres JA (2009) Short-term dynamics of late-winter phytoplankton blooms in a temperate ecosystem (Central Cantabrian Sea, Southern Bay of Biscay). J Plankton Res 31:601-617

Álvarez E, López-Urrutia Á, Nogueira E, Fraga S (2011) How to effectively sample the plankton size spectrum? A case study using FlowCAM. J Plankton Res 33:1119-1133

Álvarez E, López-Urrutia Á, Nogueira E (2012) Improvement of plankton biovolume estimates derived from image-based automatic sampling devices: application to FlowCAM. J Plankton Res 34:454-469

Arin L, Morán XAG, Estrada M (2002) Phytoplankton size distribution and growth rates in the Alboran Sea (SW Mediterranean): short term variability related to mesoscale hydrodynamics. J Plankton Res 24:1019-1033

Baird ME, Ralph PJ, Rizwi F, Wild-Allen K, Steven ADL (2013) A dynamic model of the cellular carbon to chlorophyll ratio applied to a batch culture and a continental shelf ecosystem. Limnol Oceanogr 58:1215-1226

Behrenfeld MJ, Marañón E, Siegel DA, Hooker SB (2002) Photoacclimation and nutrient-based model of lightsaturated photosynthesis for quantifying oceanic primary production. Mar Ecol Prog Ser 228:103-117 
Behrenfeld MJ, Boss E, Siegel DA, Shea DM (2005) Carbonbased ocean productivity and phytoplankton physiology from space. Global Biogeochem Cycles 19:GB1006, doi: 10.1029/2004GB002299

- Behrenfeld MJ, Halsey KH, Milligan AJ (2008) Evolved physiological responses of phytoplankton to their integrated growth environment. Philos Trans R Soc Lond B Biol Sci 363:2687-2703

Buck KR, Chavez FP, Campbell L (1996) Basin-wide distributions of living carbon components and the inverted trophic pyramid of the central gyre of the North Atlantic Ocean, summer 1993. Aquat Microb Ecol 10:283-298

> Calvo-Díaz A, Morán XAG (2006) Seasonal dynamics of picoplankton in shelf waters of the southern Bay of Biscay. Aquat Microb Ecol 42:159-174

Calvo-Díaz A, Morán XAG, Suárez LA (2008) Seasonality of picophytoplankton chlorophyll $a$ and biomass in the central Cantabrian Sea, southern Bay of Biscay. J Mar Syst 72:271-281

> Cermeño P, Marañon E, Rodríguez J, Fernández E (2005) Large-sized phytoplankton sustain higher carbon-specific photosynthesis than smaller cells in a coastal eutrophic ecosystem. Mar Ecol Prog Ser 297:51-60

Cloern JE, Grenz C, Vidergar-Lucas L (1995) An empirical model of the phytoplankton chlorophyll/carbon ratiothe conversion factor between productivity and growth rate. Limnol Oceanogr 40:1313-1321

> Cullen JJ (1982) The deep chlorophyll maximum: comparing vertical profiles of chlorophyll a. Can J Fish Aquat Sci 39: 791-803

Dodson AN, Thomas WH (1978) Reverse filtration. In: Sournia A (ed) Phytoplankton manual. UNESCO, Paris, p 104-107

Edwards KF, Litchman E, Klausmeier CA (2013) Functional traits explain phytoplankton community structure and seasonal dynamics in a marine ecosystem. Ecol Lett 16: 56-63

Elzhov TV, Mullen KM, Spiess AN, Bolker B (2015) minpack.lm: $\mathrm{R}$ interface to the Levenberg-Marquardt nonlinear least-squares algorithm found in MINPACK, plus support for bounds. R package version 1.1-9. Available at https://cran.r-project.org/package $=$ minpack.lm (accessed on 30 November 2015)

Fernández E, Bode A (1991) Seasonal patterns of primary production in the Central Cantabrian Sea (Bay of Biscay). Sci Mar 55:629-636

Finkel ZV (2001) Light absorption and size-scaling of lightlimited metabolism in marine diatoms. Limnol Oceanogr 46:86-94

Finkel ZV, Irwin AJ, Schofield O (2004) Resource limitation alters the $3 / 4$ size scaling of metabolic rates in phytoplankton. Mar Ecol Prog Ser 273:269-279

Fujiki T, Taguchi S (2002) Variability in chlorophyll a specific absorption coefficient in marine phytoplankton as a function of cell size and irradiance. J Plankton Res 24: 859-874

García CM, Jimenez-Gómez F, Rodríguez J (1994) The sizestructure and functional composition of ultraplankton and nanoplankton at a frontal station in the Alboran Sea. Working Groups 2 and 3 report. Sci Mar 58:43-52

- Geider RJ (1987) Light and temperature dependence of the carbon to chlorophyll a ratio in microalgae and cyanobacteria: implications for physiology and growth of phytoplankton. New Phytol 106:1-34

Geider RJ, Platt T, Raven JA (1986) Size dependence of growth and photosynthesis in diatoms: a synthesis. Mar Ecol Prog Ser 30:93-104

Graff JR, Milligan AJ, Behrenfeld MJ (2012) The measurement of phytoplankton biomass using flow-cytometric sorting and elemental analysis of carbon. Limnol Oceanogr Methods 10:910-920

> Granda AP, Anadón R (2008) The annual cycle of nanoflagellates in the Central Cantabrian Sea (Bay of Biscay). J Mar Syst 72:298-308

Grasshoff K, Ehrhardt M, Kremling K (1983) Methods of seawater analysis, $2^{\text {nd }}$ edn. Verlag Chemie, Weinheim/Deerfield Beach, FL

Gutiérrez-Rodríguez A, Latasa M, Estrada M, Vidal M, Marrasé C (2010) Carbon fluxes through major phytoplankton groups during the spring bloom and postbloom in the Northwestern Mediterranean Sea. Deep Sea Res I 57:486-500

Heldal M, Scanlan DJ, Norland S, Thingstad F, Mann NH (2003) Elemental composition of single cells of various strains of marine Prochlorococcus and Synechococcus using X-ray microanalysis. Limnol Oceanogr 48:1732-1743

> Herzig R, Falkowski PG (1989) Nitrogen limitation in Isochrysis galbana (Haptophyceae). 1. Photosynthetic energy conversion and growth efficiencies. J Phycol 25:462-471

$>$ Huot Y, Babin M, Bruyant F, Grob C, Twardowski MS, Claustre H (2007) Does chlorophyll a provide the best index of phytoplankton biomass for primary productivity studies? Biogeosci Discuss 4:707-745

Irwin AJ, Finkel ZV, Schofield OME, Falkowski PG (2006) Scaling-up from nutrient physiology to the size-structure of phytoplankton communities. J Plankton Res 28: 459-471

- Kara AB, Rochford PA, Hurlburt HE (2000) An optimal definition for ocean mixed layer depth. J Geophys Res 105: 16803-16821

Key T, McCarthy A, Campbell DA, Six C, Roy S, Finkel ZV (2010) Cell size trade-offs govern light exploitation strategies in marine phytoplankton. Environ Microbiol 12:95-104

Kirk JTO (1994) Light and photosynthesis in aquatic ecosystems, $3^{\text {rd }}$ edn. Cambridge University Press, New York, NY

- Le Bouteiller A, Leynaert A, Landry MR, Le Borgne R and others (2003) Primary production, new production, and growth rate in the equatorial Pacific: changes from mesotrophic to oligotrophic regime. J Geophys Res 108: $8141-8156$

$>$ Legendre L (1990) The significance of microalgal blooms for fisheries and for the export of particulate organic carbon in oceans. J Plankton Res 12:681-699

Litchman E, Klausmeier CA (2008) Trait-based community ecology of phytoplankton. Annu Rev Ecol Evol Syst 39: $615-639$

Marañón E, Cermeño P, Rodríguez J, Zubkov MV, Harris RP (2007) Scaling of phytoplankton photosynthesis and cell size in the ocean. Limnol Oceanogr 52:2190-2198

McGill BJ, Enquist BJ, Weiher E, Westoby M (2006) Rebuilding community ecology from functional traits. Trends Ecol Evol 21:178-185

> Menden-Deuer S, Lessard EJ (2000) Carbon to volume relationships for dinoflagellates, diatoms and other protist plankton. Limnol Oceanogr 45:569-579

Morán XAG, Scharek R (2015) Photosynthetic parameters and primary production, with focus on large phytoplankton, in a temperate mid-shelf ecosystem. Estuar Coast 
Shelf Sci 154:255-263

Neveux J, Panouse M (1987) Spectrofluorometric determination of chlorophylls and pheophytins. Arch Hydrobiol 109:567-581

Olson RJ, Zettler ER, DuRand MD (1993) Phytoplankton analysis using flow cytometry. In: Kemp PF, Sherr BF, Sherr EB, Cole JJ (eds) Handbook of methods in aquatic microbial ecology. Lewis Publishers, Boca Raton, FL, p 175-186

Peliz A, Dubert J, Santos AMP, Oliveira PB, Le Cann B (2005) Winter upper ocean circulation in the Western Iberian Basin-fronts, eddies and poleward flows: an overview. Deep Sea Res I 52:621-646

Pérez V, Fernández E, Marañón E, Morán XAG, Zubkov MV (2006) Vertical distribution of phytoplankton biomass, production and growth in the Atlantic subtropical gyres. Deep Sea Res I 53:1616-1634

Pingree RD, LeCann B (1990) Structure, strength and seasonality of the slope currents in the Bay of Biscay region. J Mar Biol Assoc UK 70:857-885

Rodriguez J (1994) Some comments of the size-based structural analysis of the pelagic ecosystems. Sci Mar 58:1-10

Rodriguez J, Mullin MM (1986) Relation between biomass and body weight of plankton in a steady state oceanic ecosystem. Limnol Oceanogr 31:361-370

Sakshaug E, Andresen K, Kiefer DA (1989) A steady state description of growth and light absorption in the marine planktonic diatom Skeletonema costatum. Limnol Oceanogr 34:198-205

Saux Picart S, Sathyendranath S, Dowell M, Moore T, Platt T (2014) Remote sensing of assimilation number for marine phytoplankton. Remote Sens Environ 146:87-96

Siegel DA, Maritorena S, Nelson NB, Hansell DA, LorenziKayser M (2002) Global distribution and dynamics of colored dissolved and detrital organic materials. J Geophys

Editorial responsibility: Graham Savidge,

Portaferry, UK
Res 107:3228

> Sieracki CK, Sieracki ME, Yentsch CS (1998) An imagingin-flow system for automated analysis of marine microplankton. Mar Ecol Prog Ser 168:285-296

Sosik HM, Chisholm SW, Olson RJ (1989) Chlorophyll fluorescence from single cells: interpretation of flow cytometric signals. Limnol Oceanogr 34:1749-1761

> Vázquez-Domínguez E, Morán XAG, López-Urrutia A (2013) Photoacclimation of picophytoplankton in the central Cantabrian Sea. Mar Ecol Prog Ser 493:43-56

Wang XJ, Behrenfeld M, Le Borgne R, Murtugudde R, Boss E (2009) Regulation of phytoplankton carbon to chlorophyll ratio by light, nutrients and temperature in the equatorial Pacific Ocean: a basin-scale model. Biogeosci 6:391-404

Wang X, Murtugudde R, Hackert E, Marañón E (2013) Phytoplankton carbon and chlorophyll distributions in the equatorial Pacific and Atlantic: a basin-scale comparative study. J Mar Syst 109-110:138-148

> Westberry T, Behrenfeld MJ, Siegel DA, Boss E (2008) Carbon-based primary productivity modeling with vertically resolved photoacclimation. Global Biogeochem Cycles 22:GB2024, doi:10.1029/2007GB003078

Worden AZ, Nolan JK, Palenik B (2004) Assessing the dynamics and ecology of marine picophytoplankton: the importance of the eukaryotic component. Limnol Oceanogr 49:168-179

Yentsch CM, Horan PK, Muirhead K, Dortch Q and others (1983) Flow cytometry and cell sorting: a technique for analysis and sorting of aquatic particles. Limnol Oceanogr 28:1275-1280

Zubkov MV, Sleigh MA, Tarran GA, Burkill PH, Leakey RJG (1998) Picoplankton community structure on an Atlantic transect from $50^{\circ} \mathrm{N}$ to $50^{\circ} \mathrm{S}$. Deep Sea Res I 45: 1339-1355

Submitted: February 10, 2015; Accepted: December 6, 2015 Proofs received from author(s): January 20, 2016 